Spośród XVI-wiecznych poloników trzy pozycje nie mają not wydawcy, odsyłających czytelnika do Bibliografii polskiej Estreicherów. Są to: 26-21, 29-54 i 29-56. Wśród nich druga odnosi się do Philosophia pauperum Alberta Wielk1ego. Notuje ją katalog tyniecki jako Alberti Magni philosophía naturalis in $4^{\circ}$ Cracoviae a. 1519. Na tej samej stronie przy poz. 47 podaje katalog: Naturalis philosophiae Alberti Magni in $4^{\circ}$ fol., Cracoviae 1510. Notka wydawcy przy tej pozycji odsyła do Estr. t. $12 \mathrm{~s}$. 98, nie zaznaczając wszakże, że opis Bibliografii polskıe podaje inny rok wydania, a mianowicie 1516. Nie ulega wątpliwośc1, że opisy katalogu tynieckiego podają błędną datę wydania tego dziełka. Na podstawie badań Aleksandra Birkenmajera wiemy, że dwa tylko wydania krakowskie Filozofii ubogich miały format 40 - z r. 1508 i 1516. Oba troczone u Hallera ${ }^{5}$.

Czy biblioteka tyniecka posiadała dwa różne wydania, czy raczej dwa egzemplarze jednego 1 tego samego dziełka, trudno z całą pewnoścıą rozstrzygnąć. Sam falkt wszakże nabycia przez Mieleckiego dwóch tekstów tej księżeczki, „,której powodzenie można zrozumieć $w$ epoce zdegenerowanej scholastyki wreku XV, lecz która już $w$ dobrych czasach średniowıecza raziła czytelników a na tle czasów nowożytnych była niepojętym anachronizmem" " reformatorskiej dostrzec można pewne rysy świadczące o koncesjach na rzecz dawnych nawyków myślowych.

Naturalnie nie można wyprowadzać z tego pojedynczego faktu daleko idących wniosków ogólnych, ale dokonana przeze mnie próba identyfikacji niektórych pozycji katalogu tynieckiego dowodzi potrzeby bardziej gruntownych badań bibliograficzno-analitycznych. Opublikowanie zaś katalogu tynıckiego wraz z rozprawą znakomitego znawcy dziejów naszej kultury w osobie Stanısława Estreichera, współpracownika i kontynuatora dzieła swojego ojca na polu rejestracji polskiego piśmiennictwa, jest niewątpliwie wielkim dla tych badań ułatwieniem. Toteż za dokonanie tego należy się prawdziwa wdzięczność prof. Karolowi Estreicherowi.

Witold Nowodworski

\title{
JERZY STARNAWSKI
}

\section{NAGROBEK ŁUKASZA GÓRICKIEGO, SYNA PISARZA W KATEDRZE FROMBORSKIEJ}

Autorowi Dworzanina wystawili nagrobek w Tykocinie dwaj synowie: Eukasz i Jan. Znamy go $z$ przekładu polskiego, ogłoszonego drukiem $w$ naszym stuleciu ${ }^{1}$. Powrót Warmii do Polski, a wraz z Warmią katedry fromborskiej, nakazuje przypomnieć o istnieniu dwu jeszcze nagrobków Górnıckich, z których jeden poświęcony jest bratu, drugi - synowi pisarza. Pierwszy z wymienionych, opowiadający dzieje Pawła Górnickiego (1555-1632), piastującego godności dworskie

s A. Birkenmajer: Krakowskie wydania tak zwanej Philosophia pauperum Alberta Wielkıego. Exlibris, $6: 1924$ s. 21-23.

- Tamze s. 25.

1 Por. M. M lt uła: Zycie Gónnickiego w świetle dotychczasowych badań. Przeszzośc 1930 nr 7. 
i kościelne, wygnanego z Fromborka przez Szwedów, nagrobek wystawiony stryjowi przez Łukasza, syna Eukasza, był już od dawna znany z Monumenta Sarmatarum Szymona Starowolskiego ${ }^{2}$.

Natomiast prawie nieznany pozostal dotąd nagrobek owego Łukasza - syna (1585-1651), umieszczony naprzeciw nagrobka stryja w katedrze fromborskiej, wystawiony zapewne już po zwiedzeniu świątyni przez Starowolskiego i dlatego przezeń nie zanotowany, wymieniany wprawdzie przez badaczy niemieckich i polskich ${ }^{3}$, dotąd wszakże nie ogłoszony in extenso. Tekst nagrobka brzmi.

\section{O. M.}

Viator, siste gradum, aeternitatem cogita et piis manibus bene precare. Lucas Górncki, praepositus Varmıensis, can[onic]us vilnensıs Luca Górnıckı, Ticocin[ensi], Vasilcov[iensi] cap[ita]neo et Barbarae de Bezdżedźa " Broniewska, parentibus avilae nobilitatis ortus, d[ominorum], d[ominorum] Sigism[undi] III, Vladisl[ai] IV, Ioan[nIs] Casim[iri], Polon[iae] succ[edentium] regum, s[e]c[reta]rus. Religionem, pietatem, ita cum fide, líberalitate, candore coniunxit, ut principum gratia pro vurtutis censu ornaretur. Quanto meritis clarıor tanto anımo moderatior. Quem nec ullo oblatae unfulae ambitu expugnarunt. Tam egregior1s animi dotibus constitutus, dum pro venceslao comite a Lessno, principe, ep[isco]po Varmien[si], prudenter ep[iscopjatum moderatur et maiora virtuti praema parat, magno Eccles]iae et Patriae cum luctu, triste su relinquens desiderium, exspirat, Natus an[nos] LXVI, d[ies] XX, obiit an[no] MDCLI, d[ie] XV Julii, Ioannes a Glow[na] Górnıck1, nepos moerens patruo desideratissimo p[ostumentum] p[osuit].

Nagrobek ów charakteru wyraźnie barokowego, to świadectwo sławy i znaczenia rodu Górnickich $\mathrm{w}$ wieku XVII i zarazem krótkie curriculum vitae Eukasza - syna, jak również świadectwo istnienia Jana Górnickiego, wnuka pisarza. Słowa: parentibus avilae nobilitatis ortus, zapisane już $\mathrm{w}$ drugiej połowie XVII w., nie są oczywiście dowodem szlachectwa autora Dworzanına, którego, jak wiemy, spotkało vituperatio nobilitatis. Łukasz - syn byl już na pewno urodzony $w$ szlacheckim stanie, jeśli nawet przyjąć, że Eukasz - ojciec został uszlachcony dopiero $w$ r. 1555 (data wygrania procesu z Łukaszem Oleśnickim skarżającym go o nieprawne posiadanie szlachectwa), lub nawet w r. 1561 (data definitywnego potwierdzenia szlachectwa Gornickiego). Whuk Jan, stawiający swemu stryjowi nagrobek $w$ dziewięćdziesiąt przynajmniej lat od daty przyznania szlachectwa dziadkowi, mógł nie pamiętać, kiedy szlachectwo zostało przyznane.

Czy zaś nagrobek z krakowskiego kościoła Wszystkich Swiętych, zanotowany w Monumenta Sarmatarum Starowolskiego ${ }^{5}$, a nigdy dotąd nie włączany w orbitę badań przez biografów pisarza, nagrobek lapidarny, głoszący:

Hic iacet dominus Lucas Gurnicki proconsul

Cracoviensis. Extremum diem clausit anno MDLI -

ma $\mathrm{z}$ autorem Dworzanina coś wspólnego? Odpowiedź conajmniej kłopotliwa. Pewniejszą uzyskamy wówczas, gdy wypłyną - raczej przy okazji - inne akta dotyczące krakowskiego burmistrza zmarłego w r. 1551, np. krakowskie akta miejskie $z$ pierwszej połowy XVI $w$. Burmistrz ów nie otrzymał nawet hasła

2 Cracoviae $1655 \mathrm{~s}$. 375 . - Za Starowolskim przytacza ow nagrobek R. L ö wen f e Id: Lukasz Gornicks. Seln Leben und seme Werke. Breslau 1884; przekład polski - Warszawa 1884. W wersji polskiej s. 19.

3 Por. krótka bıografię tukasza Górnıkıego - syna w* A. El ch horn. Die Prälaten des ermländischen Domcapitels. Zeitschrift für die Geschıchte und Altertumskunde Ermlands. Bd. $3.1864 / 1866$ s. 326-328. - Zob. również F. D 1 t t $1 \mathrm{ch}$ : Böttichers Inventarısation der Bau-und Kunstdenkmäler Ermlands, Tamze. Bd. $11: 1894 / 1897$ s. 288-289. - Por. przede wszystkim K. Gó r s ki: Górnicki Eukasz (1585-1651) w Pol. stown. biogr. (VIII s. 428-429).

4 Bieźdzıedza, wieś w pow. Jasielskım, woj. rzeszowskım.

Dz. cyt. s. 68 . 
w Polskim Stowniku Biograficznym. Ale gdybyśmy nawet mogli Łukasza Górnickiego, burmistrza krakowskiego, zaliczyć z całą pewnością do galerii przodków Eukasza Górnickiego, autora Dworzanina, nie podważa to ustaleń Stanisława Windakiewicza o mieszczańskim pochodzeniu pisarza ${ }^{6}$, gdyż burmistrzem bywał w owych latach mieszczanin, oczywiście zamoźny.

Natomiast zebrany materıał pozwala wysnuć wniosek o długotrwałej wybitnej pozycji rodu Górnickich w pokoleniach następnych po Eukaszu. Stawianie nagrobków $w$ kościołach dowodziło pielęgnowania tradycji, świadczyło o kulturze umysłowej i... materialnej, bo i złotem trzeba było sypnąc mocno, by uwiecznić kogoś z swych przodków w epitafium, które przetrwa wieki.

- Kরilka słów o Łukaszu Górnickım i jego rodzınıe. Bibliot. warsz. R. 1887 t. 3 s. $369-370$. 